УДК [378.016:373.5.011.3-051]:378.147.018.43

DOI: 10.37026/2520-6427-2021-106-2-43-47

\section{Олена ШУРИН,}

кандидат педагогічних наук, доцент кафедри професійної освіти, трудового навчання та технологій

Рівненського державного гуманітарного університету, м. Рівне, Украӥна

ORCID: 0000-0002-8804-7860

e-mail: olena.shuryn@rshu.edu.ua

\title{
АКТУАЛЬНІ ПИТАННЯ ПРОФЕСІЙНОЇ ПІДГОТОВКИ МАЙБУТНІХ УЧИТЕЛІВ ТЕХНОЛОГІЧНОГО ПРОФІЛЮ В УМОВАХ ДИСТАНЦЙНОГО НАВЧАННЯ
}

\begin{abstract}
Анотація. У статті обтрунтовано важливість підготовки майбутніх учителів технологічного профілю в сучасній освітній системі. Досліджено теоретичну складову підготовки майбутніх учителів. Особливу увагу приділено розвитку творчої особистості майбутнього вчителя-професіонала, який не лише має володіти теоретичними знаннями, вміннями, навичками та вміло їх застосовувати у професійній діяльності, а й сучасними засобами здійснення навчально-виховного процесу, зокрема інформаційно-комунікаційними технологіями, навичками роботи з комп'ютерною технікою.

Проаналізовано освітній процес в умовах дистанційного навчання. Схарактеризовано поняття «дистаниійне навчання» та «дистанційна освіта», відмінність дистаниійного навчання від традиційного.
\end{abstract}

Окреслено основні переваги (актуальність використання найсучасніших засобів для здобуття інформаиії, безперервність навчання, відсутність географічних бар 'єрів тощо) та недоліки (ускладнена ідентифікація студентів, низька пропускна спроможність електронної мережі під час навчальних чи екзаменаційних телеконференцій, недостатній безпосередній контакт між викладачем та студентом, унеможливлення вивчення окремих видів творчої діяльності, відсутність відповідного технічного оснащення та можливості доступу до мережі Інтернет тощо) здійснення професійно-педагогічної підготовки майбутніх учителів технологічного профілю в умовах дистаниійного навчання.

Ключові слова: професійно-педагогічна підготов$\kappa a$, дистанщійне навчання, інформаційно-комунікаційні технології, дистаниійна освіта, педагогічний процес.

\author{
Olena SHURYN, \\ PhD in Pedagogy, \\ Associate Professor of Vocational Education, \\ Labor Training and Technology \\ Rivne State University for the Humanities, \\ Rivne, Ukraine \\ ORCID: 0000-0002-8804-7860 \\ e-mail: olena.shuryn@rshu.edu.ua
}

\section{CURRENT ISSUES OF PROFESSIONAL TRAINING OF FUTURE TEACHERS OF TECHNOLOGICAL PROFILE IN THE CONDITIONS OF DISTANCE LEARNING}

\begin{abstract}
The important role of training future teachers in the modern educational system is substantiated, in particular, attention is focused on the development of creative, active personality of the future professional teacher, who would not only have theoretical knowledge and skills implementation of the educational process, in particular information and communication technologies, computer skills. The difference between distance and distance learning is explained. The theoretical component of teacher training, as well as the implementation of the educational process in terms of distance learning. The
\end{abstract}

concepts of «distance learning» and «distance education», the difference between distance learning and traditional. The main advantages of distance learning are studied (relevance of using the most modern means to obtain information, continuity of learning, mobility of the educational process, learning in comfortable conditions and at a convenient time, the absence of geographical barriers, etc.). The shortcomings of professional and pedagogical training of future teachers in the conditions of distance learning (complicated identification of distance students, low bandwidth of the electronic network during 
educational or examination teleconferences, insufficient direct contact between teacher and distance student, inability to study certain creative activities, lack of personal communication are analyzed, unsystematic education of students with low motivation to get an education and insufficient level of self-organization, lack of appropriate technical equipment and access to the Internet, etc.). It is concluded that the quality of training of future teachers and the formation of their readiness to use information technology in future professional activities depends on the material base of higher education, personal capabilities of teachers themselves, including material, their professional level.

Key words: professional and pedagogical training, distance learning, information and communication technologies, distance education, pedagogical process.

Постановка проблеми. Пріоритетним напрямом сучасної освіти $€$ становлення і розвиток активної, творчої особистості із чітко вираженою суб'єктною позицією, здатної швидко адаптуватися до умов швидкозмінного суспільства. Важлива роль у цьому процесі належить педагогам, професійна підготовка яких вимагає постійної модифікації, пошуку нових підходів, педагогічних технологій, прийомів та засобів (Осадчий, 2010). Водночас підготовка педагогічних кадрів потребує фахівців нового покоління, які б не тільки мали високий рівень знань та вміли застосовувати їх у професійній діяльності, а й володіли сучасними засобами здійснення освітнього процесу.

В умовах карантинних обмежень освітній процес, звичайно, модернізується, відбувається перехід від традиційного навчання до дистанційного, яке передбачає використання новітніх технологій, які дають змогу підвищити та вдосконалити ефективність навчальної діяльності. У процесі реформування освітньої галузі в закладах вищої освіти (далі - 3ВO) впроваджується концепція дистанційної освіти, що має на меті розробку різноманітних технологій, зокрема технології змішаного навчання (Андрусенко, 2017, с. 7). Потреба отримання вищої освіти дистанційно викликана нині не лише вимушеними карантинними умовами, спричиненими пандемією COVID-19, а й необхідністю навчатися без відриву від виробництва, можливістю отримання освіти людьми з особливими потребами тощо (Власенко, 2017, c. 12-14).

Аналіз наукових досліджень і публікацій. Питанням підготовки педагогічних кадрів присвячено праці таких учених, як В. Андрущенко, А. Бойко, Я. Болюбаш, С. Вітвицька, В. Глузман, О. Дубасенюк, І. Зязюн, Т. Кісіль, Т. Коваль, В. Кремінь, В. Осадчий, В. Саюк, О. Саюк, С. Сисоєва, В. Ципко та ін.

Різні аспекти впровадження і використання інформаційно-комунікаційних технологій у закладах вищої освіти, а також проблеми застосування дистанційної форми у процесі підготовки педагогічних працівників розглядали О. Андрєєв, Н. Андрусенко, В. Артюшенко, С. Архангельський, Ю. Бабанський, О. Блажко, М. Бухаркіна, Я. Ваграменко, Т. Вахрущева, В. Вержбіцький, К. Верішко, І. Власенко, О. Воронкін, Г. Даценко, Є. Долинський, Т. Єфименко, 3. Сузанська, В. Каймін, М. Загірняк, Н. Клокар, Г. Козлакова, І. Козубовська,
Т. Костунець, І. Кузьміна, В. Кухаренко, О. Матюшкін, М. Махмутова, І. Огороднік, В. Олійник, В. Осадчий, Є. Полат, О. Рибалко, Л. Романишин, Н. Самолюк, Н. Сиротенко, А. Хуторський, М. Швець та ін.

Однак, незважаючи на значну кількість наукових досліджень, в яких окреслено досвід професійно-педагогічної підготовки майбутніх учителів, зокрема й технологічного профілю, потребують подальшого дослідження та вивчення питання впровадження та результативності сучасної дистанційної освіти в Україні, яка в багатьох випадках все ще нагадує традиційні форми заочного навчання, без застосування всіх можливостей новітніх форм і методів провадження освітньої діяльності (Андрусенко, 2017, с. 7-9).

Мета статті - проаналізувати підготовку майбутніх учителів технологічного профілю у процесі організації дистанційного навчання, визначити їхню готовність до такої діяльності; проаналізувати основні кроки для впровадження означеної форми навчання в освітній процес.

Виклад основного матеріалу дослідження. Умовою досягнення якості вищої освіти є високий професійний рівень науково-педагогічних працівників. Більшість дослідників розглядають професійну підготовку вчителя як процес оволодіння особистістю життєвими компетенціями, загальнонауковими, професійними знаннями й уміннями, необхідними для успішного здійснення професійної діяльності.

В. Осадчий зауважує, що головним завданням у процесі підготовки вчителя є перетворення особистості студента в учителя-професіонала, спроможного вирішувати різноманітні питання, пов'язані з навчанням, вихованням і розвитком учнів. Відповідно у професійній діяльності майбутнього педагога значну роль відіграє теоретична підготовка, спрямованість студентів на неперервний професійний розвиток, самовдосконалення, розкриття внутрішнього потенціалу, творчість (Осадчий, 2010).

На сучасному етапі розвитку суспільства Україна потребує вчителя нового покоління. У зв'язку з цим педагог зобов'язаний не тільки засвоїти теоретичні знання, а й володіти вміннями організаційної та виховної роботи, виявляти ініціативу, бути відповідальною, висококультурною особистістю, яка знає іноземну мову, прагне до самовдосконалення і самоосвіти, впроваджує інновації, працює з комп’ютерною технікою.

Використання комп'ютерної техніки та інформаційних технологій значно підвищує ефективність процесу навчання завдяки його індивідуалізації, можливості здійснення зворотного зв’язку (Кузьміна, 2011). Як наслідок - виникла досить перспективна, орієнтована на індивідуалізацію нова форма освітнього процесу - дистанційне навчання, що, з одного боку, дозволяє значно скоротити витрати на підготовку фахівців, зменшивши навантаження на державний бюджет, а 3 іншого - полегшує отримання освіти представникам соціально вразливих верств населення, особам 3 особливими потребами, молоді, якій складно поєднувати навчання та роботу, а також людям, які проживають у віддаленій від обласних центрів місцевості, військовослужбовцям, домогосподаркам, керівникам, бізнесменам або студентам, які бажають отримати 
додаткову освіту. Дистанційна форма навчання є одним з основних способів реалізації навчального процесу в умовах карантинних обмежень, які унеможливлюють здійснення традиційної форми навчання (Самолюк, Швець, 2013, с. 193).

На сьогодні науковці не можуть дійти одностайного рішення щодо визначення поняття «дистанційне навчання»: означений термін ототожнюють із дуже близьким до нього поняттям - «дистанційна освіта» (Андрусенко, 2017, с. 7).

Дистаниійне навчання - це технологія, що базується на принципах відкритого навчання, широко використовує комп'ютерні навчальні програми різного призначення та створює за допомогою сучасних телекомунікацій інформаційне освітнє середовище для постачання навчального матеріалу та спілкування (Андрусенко, 2017, с. 7). Відповідно дистанційна освіта - форма навчання, рівноцінна $з$ очною, вечірньою, заочною та екстернатом, що зазвичай реалізується за технологіями дистанційного навчання (Андрусенко, 2017, с. 7-9)

Дистанційне навчання розглядається як форма організації освіти, коли студенти віддалені від викладача у просторі та часі, але можуть підтримувати діалог із ним за допомогою засобів комунікації. Надання доступу до навчальних матеріалів, рекомендацій щодо роботи 3 ними відбувається у зручному місці та в зручний час. Це дозволяє знизити кількість аудиторних занять у загальному навантаженні студента, звільнити час для більш активної самостійної роботи, забезпечити індивідуалізацію навчання. Така організація процесу навчання припускає дещо інший підхід до навчання, а саме: самостійність пошуку, аналізу, систематизації та узагальнення інформації, самоорганізацію й самоконтроль (Даценко, Сузанська, 2017, с. 17).

Відмінність дистанційного навчання від традиційного легко зрозуміти, якщо розглянути їх із погляду форм взаємодії у системі «викладач - студент». В основу традиційної моделі навчання покладено читання лекцій, проведення семінарських і лабораторних занять, різноманітних ігрових видів занять, організацію самостійної роботи студентів тощо. База навчання у цьому випадку - книга і викладач як інтерпретатор знання. Дистанційне ж навчання орієнтоване на впровадження в освітній процес принципово відмінних моделей навчання, що передбачають проведення конференцій, проєктних робіт, тренінгів, інших видів діяльності, використовуючи комп'ютерні та нетрадиційні технології (Даценко, Сузанська, 2017, с. 17).

Досить часто дистанційне навчання плутають із заочною освітою. Однак це не одне і теж. Так, якщо студент, навчаючись заочно, зустрічається з викладачем лише на лекціях та іспитах, а основний матеріал освоює самостійно, то в процесі дистанційного навчання між викладачем та студентом наявний постійний онлайн-зв'язок та «живе» спілкування за допомогою комп'ютерних технологій (Самолюк, Швець, 2013, с. 193).

Серед основних переваг дистаниійного навчання вчені (Н. Андрусенко, О. Блажко, І. Власенко, І. Кузьміна та ін.) виділяють:

- актуальність, що передбачає використання найсучасніших засобів для здобуття інформації, IКТ та можливостей мережі «Інтернет» (Блажко, Костунець, 2017 , с. $10-11)$;

- безперервність навчання, можливість навчатися в будь-який момент за індивідуальним графіком; мобільність, можливість поєднання кількох освітніх напрямів;

- відсутність необхідності відвідувати лекції та семінари; комплексне програмне забезпечення; провідні освітні технології (Кузьміна, 2011);

- постійний контакт із викладачем за допомогою телекомунікаційних технологій (не виходячи 3 дому або не покидаючи робочого місця);

- структурований навчальний матеріал, представлений в електронному вигляді, порівняно більші обсяги інформації, яку можна отримати в умовах дистанційного навчання у коротші терміни;

- доступ до нетрадиційних джерел інформації;

- підвищення ефективності самостійної роботи, абсолютно нові можливості для творчого самовираження, знаходження та закріплення професійних навичок; можливість викладачам реалізовувати абсолютно нові форми і методи навчання (Андрусенко, 2017, с. 7);

- зручність, за якої кожен студент має можливість обрати власний ритм і режим отримання знань у комфортній для нього обстановці;

- доступність, що передбачає економію часу та коштів завдяки використанню навчальних приміщень та представлення вільного доступу до освітніх матеріалів (Блажко, Костунець, 2017, с. 10; Власенко, 2017, с. 12);

- гнучкість, яка надає можливість викладати матеріал відповідно до рівня підготовки та базових знань студентів, створюючи додаткові сайти 3 необхідною інформацією та сайти, на яких студенти можуть обмінюватися інформацією, відповідаючи на запитання один одного та навчатися, навчаючи інших;

- відсутність географічних бар'єрів, за якої відпадає необхідність дорогого переїзду та проживання в інших країнах, а натомість надається можливість без обмежень спілкуватися з викладачами та студентами по всьому світу (Блажко, Костунець, 2017, с. 10).

Хоча перелік переваг дистанційної форми навчання досить великий, проте означений спосіб провадження освітнього процесу має й певні недоліки, як-от:

- ускладнена ідентифікація студентів, які перебувають на дистанційному навчанні, оскільки на сучасному етапі розвитку інформаційних технологій перевірити те, хто саме складає іспит, досить важко (Кузьміна, 2011);

- складність організації спільних видів діяльності 3 метою комунікації та обміну досвідом;

- недостатній безпосередній контакт між викладачем та студентом (менш ефективна, безособистісна передача знань) (Кузьміна, 2011; Блажко, Костунець, 2017, c. 10);

- неабиякі труднощі у самостійному вивченні деяких видів творчої діяльності (Блажко, Костунець, 2017 , c. 10);

- можливість навчатися у зручний час може перетворитися не на систематичне навчання, а на постійну прокрастинацію цього виду діяльності (саме тому дистанційна форма потребує особливої мотивації до навчання, а також самоорганізованості та вміння розрахувати свій час); 
- низька пропускна спроможність електронної мережі під час навчальних чи екзаменаційних телеконференцій (від цього передусім страждають студенти невеликих містечок України, яким, до речі, найбільше підходить дистанційна освіта у зв'язку з географічною віддаленістю від наукових осередків) (Кузьміна, 2011; Самолюк, Швець, 2013, с. 193);

- не всі студенти в змозі забезпечити себе достатнім технічним обладнанням; недосконалість нормативно-правового й організаційно-методичного забезпечення (відсутність нормативних документів з боку держави, цільової державної програми з розвитку дистанційної освіти, а також методичних засад застосування дистанційних технологій відповідно до наявних напрямів підготовки і спеціалізацій;

- низький захист авторського права на електронні навчальні видання;

- відсутність норм часу на розробку електронних медійних навчальних видань);

- недостатня кваліфікація викладачів та проблема їхньої підготовки й перепідготовки (консерватизм, психологічний бар'єр, непідготовленість науково-педагогічних кадрів;

- інертність до нововведень; низький мотиваційний рівень до розробки дистанційних курсів та роботи за дистанційними технологіями) (Кузьміна, 2011; Самолюк, Швець, 2013, с. 193);

виникнення перебоїв у доступі до віддалених ресурсів, що може призвести до втрати або пошкодження даних;

- труднощі у фінансуванні розробок дистанційних технологій, оновленні комп'ютерної техніки та матеріальної бази, забезпеченні доступу викладачів до мережі Інтернет;

- значне навантаження на зір у зв'язку з необхідністю тривалий час перебувати за комп'ютером (Власенко, 2017, с. 12).

За умови дистанційного навчання активна роль викладача не применшується, оскільки він має визначити рівень знань здобувача та прийняти рішення щодо коригування програми навчання 3 тим, щоб домогтися найкращого засвоєння пройденого матеріалу (Власенко, 2017, с. 12).

Таким чином, упровадження дистанційного навчання у закладах вищої освіти передбачає організацію якісного освітнього процесу з використанням новітніх інформаційно-комунікаційних засобів та відкритим доступом до освітніх ресурсів. Однак якість навчання майбутніх учителів, зокрема і технологічного профілю, формування їхньої готовності до використання інформаційних технологій у майбутній професійній діяльності залежить від матеріальної бази закладу освіти, особистісних можливостей викладачів, зокрема й матеріальних, їхнього професійного рівня. Сучасна інформаційна підготовка викладачів у педагогічних ЗВО загалом орієнтована на формування окремих знань, умінь, навичок у галузі інформатики та інформаційних технологій, готовності до їх застосування у професійній діяльності, чого, однак, в інформаційному суспільстві недостатньо.

Висновки. Отже, підсумовуючи викладене вище, зауважимо, що впровадження дистанційного навчання в Україні нині на часі. Це урізноманітнить процес навчання, зробить його інтерактивним, дозволить оптимізувати час, якого завжди бракує на якісне освоєння матеріалу. За таких умов головною метою закладу освіти має стати виховання в здобувачів освіти таких необхідних навичок, як уміння працювати в команді, спілкуватися, ставити мету та досягати іiі. Усе це можливо лише в тісній співпраці студентів та викладача.

Однак для того, щоб дистанційне навчання зайняло гідне місце в системі вітчизняної освіти, потрібно вдосконалити законодавче та нормативне забезпечення, створити глобальну комп’ютерну мережу освіти й науки, адже комп'ютер у теперішніх умовах - це не лише інструмент для отримання навчального матеріалу, а ще й бібліотека, центр довідкової інформації, комунікативний центр тощо.

Перспективи подальших досліджень убачаємо в необхідності створення та розробки дистанційних курсів на різних електронних платформах, удосконалення системи оцінювання завдань, що виконуються здобувачами освіти дистанційно, підвищення мотивації всіх учасників процесу дистанційного навчання.

\section{СПИСОК ВИКОРИСТАНОЇ ЛІТЕРАТУРИ}

Осадчий, В. В. (2010). Проблеми організації професійної підготовки майбутніх учителів у педагогічній теорії. Науковий вісник Донбасу: електронне наукове видання. URL: http://nbuv.gov.ua/UJRN/nvd 2010110 (дата звернення: 17.02.2021).

Андрусенко, Н. В. (2017). Дистанційне навчання в Україні. Дистанційне навчання як сучасна освітня технологія: матеріали міжвузівського вебінару / відп. ред. Л. Б. Ліщинська. Вінниця: ВТЕІ КНТЕУ. С. 7-9.

Власенко, І. Г. (2017). Упровадження дистанційного навчання - вимога сучасності. Дистанційне навчання як сучасна освітня технологія: матеріали міжвузівського вебінару / відп. ред. Л. Б. Ліщинська. Вінниця: ВТЕІ КНТЕУ. С. 12-14.

Кузьміна, I. (2011). Проблеми та переваги дистанційного навчання. Новітні освітні технології: матеріали науково-практичної конференції. URL: http://confesp.fl.kpi.ua/ru/node/1031 (дата звернення: 17.02.2021).

Самолюк, Н., Швець, М. (2013). Актуальність і проблемність дистанційного навчання. Нова педагогічна думка. Рівне: РОІППО. № 1 (73). С. 193.

Даценко, Г. В., Сузанська, 3. В. (2017). Дистанційне навчання як засіб стимулювання самоосвіти. Дистаниійне навчання як сучасна освітня технологія: матеріали міжвузівського вебінару / відп. ред. Л. Б. Ліщинська. Вінниця: ВТЕІ КНТЕУ. С. 17-20.

Блажко, О. О., Костунець, Т. А. (2017). Сучасні тенденції розвитку дистанційного навчання студентів ВН3. Дистаниійне навчання як сучасна освітня технологія: матеріали міжвузівського вебінару / відп. ред. Л.Б. Ліщинська. Вінниця: ВТЕІ КНТЕУ. С. 10-11.

\section{REFERENCES}

Osadchyi, V. V. (2010). Problemy orhanizatsii profesiinoi pidhotovky maibutnikh uchyteliv u pedahohichnii teorii [Problems of organization of professional training 
of future teachers in pedagogical theory]. Naukovyi visnyk Donbasu: elektronne naukove vydannia. URL: http:// nbuv.gov.ua/UJRN/nvd_2010_1_10. (data zvernennia: 17.02.2021). [in Ukrainian].

Andrusenko, N. V. (2017). Dystantsiine navchannia v Ukraini [Distance learning in Ukraine]. Dystantsiine navchannia yak suchasna osvitnia tekhnolohiia: materialy mizhvuzivskoho vebinaru / vidp. red. L. B. Lishchynska. Vinnytsia: VTEI KNTEU. S. 7-9. [in Ukrainian].

Vlasenko, I. H. (2017). Vprovadzhennia dystantsiinoho navchannia - vymoha suchasnosti [The introduction of distance learning is a requirement of modernity]. Dystantsiine navchannia yak suchasna osvitnia tekhnolohiia: materialy mizhvuzivskoho vebinaru / vidp. red. L. B. Lishchynska. Vinnytsia: VTEI KNTEU, 2017. S. 12-14. [in Ukrainian].

Kuzmina, I. (2011). Problemy ta perevahy dystantsiinoho navchannia. [Problems and advantages of distance learning]. Novitni osvitni tekhnolohii: materialy naukovo-praktychnoi konferentsii. URL: http:/confesp. fl.kpi.ua/ru/node/1031 (data zvernennia: 17.02.2021). [in Ukrainian].
Samoliuk, N., Shvets, M. (2013). Aktualnist i problemnist dystantsiinoho navchannia [Relevance and problems of distance learning]. Nova pedahohichna dumka. Rivne: ROIPPO. № 1 (73). S. 193. [in Ukrainian].

Datsenko, H. V., Suzanska, Z. V. (2017). Dystantsiine navchannia yak zasib stymuliuvannia samoosvity [Distance learning as a means of stimulating self-education]. Dystantsiine navchannia yak suchasna osvitnia tekhnolohiia: materialy mizhvuzivskoho vebinaru / vidp. red. L. B. Lishchynska. Vinnytsia: VTEI KNTEU. S. 17-20. [in Ukrainian].

Blazhko, O. O., Kostunets, T. A. (2017). Suchasni tendentsii rozvytku dystantsiinoho navchannia studentiv VNZ [Current trends in the development of distance learning for university students]. Dystantsiine navchannia yak suchasna osvitnia tekhnolohiia: materialy mizhvuzivskoho vebinaru / vidp. red. L. B. Lishchynska. Vinnytsia: VTEI KNTEU. S. 10-11. [in Ukrainian].

Дата надходження до редакиії: 12.03.2021 p. 